\title{
JUDICIAL AND LEGAL INSTITUTIONS IN TRADITIONAL KAZAKH SOCIETY IN THE RUSSIAN RESEARCHERS' VIEW (XIX CENTURY)
}

\author{
Zh.S. Mazhitova ${ }^{1}$ \\ Valeriya Valerievna Torop ${ }^{2}$ \\ Dmitriy Aleksandrovich Singilevich ${ }^{3}$ \\ M.V. Afonin ${ }^{4}$ \\ Sergey Kurbanovich Gasanbekov ${ }^{5}$
}

\begin{abstract}
The article discusses the coverage of the Court of Biys and judicial procedural rules in Kazakh customary law by Russian prerevolutionary researchers. The authors noted that after political, administrative and legal reforms of the Russian government, the Court of Biys did not lose its significance in Kazakh society and played the role of a regulator of the socio-economic life of the nomadic community. At the same time, the merit of biys in the settlement of conflicts arising both within and at the intercommunal level between the Kazakhs is noted. According to researchers, the Court of Biys, with all its simplicity and primitiveness, contributed
\end{abstract}

to maintaining the stability of society by finding a compromise and justice through customary law. Transparency, openness and publicity of the court and the trial, the authority and respect for the beating on the part of nomads guaranteed its vitality, despite the changed political and legal conditions that arose as a result of the entry of Kazakh society into the Russian Empire.

Keywords: Russian researchers; court biys; judicial procedure; customary law

\section{Introduction}

In ancient times, on the territory of the Kazakh steppes the judicial power was concentrated in the hands of biys, 
i.e., tribal elder judges, who performed various functions in the traditional Kazakh society, including the legal ones. Carrying out administrative and legal reforms undertaken by the Russian government after the accession of the Kazakh steppe to the Russian empire in the territory of Kazakh zhuzs in the early to mid-19th century, led to a radical breakdown and transformation of traditional society. As a result, new administrative units appeared, the power of khans and sultans was abolished, and the judicial powers of biys were significantly cut. One can also specify other measures of the Russian government to make the Kazakh region got fallen under its influence. However, it should be noted that political and legal innovations modified the traditional society of the Kazakhs with great difficulty, tenaciously holding on to their old ways (Mazhitova, 2014; Mazhitova et al., 2016). One of the customs that has long been preserved in people's memory was the court of biys.

The interest in judicial legal institutes of customary law and its leaders, i.e., the biys, which arose on the part of the Russian government in the 18th century, did not fade even after the final accession of the steppes to the
Russian Empire in the second half of the 19th century. The reason for constant attention to biys can be mainly explained by the fact that biys were key figures in the Kazakh society who expressed the interests of the tribal community. Many Russian researchers, studying the norms of customary (unwritten) law and their application in judicial practice by biys (including in the trial), tried to understand what the authority of biysjudges and respect for them among nomads are based on so as to use knowledge gained to attract biys to legal activities in the interests of Russia. Thus, for example, Lazarevsky, who served in the Orenburg border commission for several years and realized the importance of biys in the Kazakh steppe, noted: "From the management of the biy, as far as I can understand the steppes, we can expect more order, tranquility and public welfare in it" [Russian State Historical Archive (RSHA). Fund. 1291. Inventory. 81. Case. 222. Sheet. 7].

Influenced by "romantic school" of Russian ethnography of the late XVIII - early XIX centuries, the researchers wanted to find confirmation of the concepts of "tribal community", "pre-class society", "people's law" in the 
Kazakh society. This goal was both theoretical and practical.

On the one hand, the appeal to the "ancient" law made it possible to draw analogies with primitive societies and compare, or rather, the "first" ones to see changes in the traditional normative practice of the Kazakhs, who had already entered the field of influence of the Russian empire. On the other hand, such studies on the "patrimonial law" of the Kazakhs were practical in nature and served as confirmation of the existence of conditions for the gradual incorporation of local law into Russian legislation.

Therefore, despite some reservations, such as "wild society", "lack of authority", etc., one can read generally positive reviews and trace the "sympathies" of researchers, who considered the local legal environment to be suitable for reform, recommended not to change it, but to use it in the course of civilizational measures to include the region in the Russian social and legal space.

\section{Methods}

One of the requirements issued to modern history researchers is a shift from descriptive style to methodological analysis of historic facts, from a mere statement of historic events to comparative analysis of material. This allows to reveal problems of a studied topic and certain aspects of the historic process (which by force of conjuncture or other reasons were left out by scientists), to objectively contrast them and on the basis of that identify perspectives for future research in order to provide knowledge continuity in the evolvement of scientific thought. In the article we used general and special scientific methods of historic and historiographical research (such as the method of objectiveness and comparative analysis).

\section{Results and Discussion}

The analysis of the problem carried out as part of this work is multidisciplinary. The scientific and theoretical problems and developments discussed in the article can form the basis of historical and legal studies on the theoretical and methodological problems of the socio-legal history of nomadic societies. In addition, materials can be used in writing special and generalizing works on the history and historiography of Kazakh society in the prerevolutionary era. 
Kazakh adat originated in a nomadic environment and developed as a legal custom of nomadic communities. Judging by the fact that it continued to operate for a long time, one can say that the adat was the most functional judicial practice among nomads.

In Kazakh customary law, there were no differences between civil and criminal cases, as in modern legislation. The type of punishment for any violations was basically the same (payment of the composition). Biys had to interpret and create legal norms that no other authority could appeal. Since there was no written codification of judicial precedents, all knowledge of the biy depended on his mastery of the oral heritage of the people, which was passed down from generation to generation, and therefore there were various versions of the law. In this regard, the ability of the biy to apply his knowledge properly and in accordance with the situation that arose demonstrated his high level as a judge and lawyer. On controversial issues, biys consulted with other elders of the society to formulate new legal rules in a nomadic collective.

In customary law, the crime meant only those actions of a nomad that caused material and moral harm to the interests of the nomadic community, which strictly followed the established law. The Kazakhs did not have a certain place of court sessions. When choosing a place proceeded from the convenience for the participants of the process: weather conditions, the range of the nomadic area, etc. Usually the consideration of large court cases was timed to some significant event in the steppe: feasts ("toi"), wakes, etc. In the process of reviewing cases, the members of the court were provided with food, housing and other amenities, the provision of which fell on the shoulders of the hosts of the event, where a large number of people always gathered. In other cases, the court session was held in the village ("aul") of the plaintiff or defendant, so that, first, all the costs associated with the organization of the court fell on their shoulders; secondly, in the case of confirmation of the defendant's guilt, the sentence of the biys was carried out immediately. Smaller (intra-clan) cases were considered in the aksakal court without much publicity and with the participation of a narrow circle of persons with a direct interest in this case.

The basis of the Kazakh community existence was the principle 
of compromise as a category of balance and stability of the collective. Although pre-revolutionary narratives noted that the Kazakhs "loved" to sue, but pointed out that many disputes ended in pre-trial procedures, primarily-a settlement agreement between the conflicting parties, which was the main purpose of the Biy court.

In the XVIII - early XIX century the Russian Empire had limited information about the adat, since its norms did not have a written codification. The image of a "lawless", "cruel" society was presented in the works of statesmen who crossed the Kazakh steppe by type of service (Nazarov, 1821; Bronevsky, 1830). For example, in the notes of the translator of a separate Siberian corps, Nazarov, sent to Kokand in 1814 , it was noted that nomadic life allows Kazakhs to avoid great subordination, therefore they "have no laws and are approved by Alcoran alone or by natural law" (Nazarov, 1821).

Nazarov drew attention to the biys, who were charged with the right to resolve judicial issues in Kazakh society. He wrote: "We came at the very time when they judged one of their congregations. Collected, at the behest of the Khan, the old biys, sitting with importance on the carpets spread across the grass, sentenced the offender to death; the sentence was executed in one minute" (Nazarov, 1821). Having become an involuntary participant in the trial, Nazarov noted several distinctive features of the court under customary law. Firstly, he differed from Russian judicial practice in his speed in resolving the case and enforcing the sentence. Secondly, in his opinion, the severe punishment imposed by the biys for the theft of cattle, which in other conditions received a completely opposite assessment. "Asked about his crime, I was very surprised to learn that he was executed for the theft of two sheep in the volost, while the very same Kyrgyz, about a private quarrel with their neighbors, go to other people's volosts at night and drive away whole herds of cattle and herds of horses, returning them only through ransom, by means of intentionally collected biys on both sides" (Nazarov, 1821).

Nazarov's description is based on the stereotype prevailing in the empire about the court of biys as "wrong" and was explained by the lawlessness that reigned in the Kazakh society. It is worth giving an explanation 
by the biys themselves of the cases of the enforcement of such sentences (judging by archival materials, such sentences were extremely rare): "There are many thieves in the steppe; tried various punishments in relation to them; we punished them - they do not let up; we imposed small penalties on them - they are not appeased; here we determined to ruin the thief in the end, so that another would not dare to steal" [RSHA. F. 1291. I. 81. C. 222. Sh. 27].

Major General S.B. Bronevsky (1830), being appointed as the chief of the Omsk Region in 1823, often went to the territory of the Middle Zhuz on duty. Correlating the traditions of Russian life with Kazakh life, he was critical of the principles of the social structure of the latter and believed that scattered Kazakh tribes, without a unifying beginning, did not represent a single political body, "which would be governed by any laws leading to the fulfillment of intentions and proposals, based on the principles of a common goal"'.

Collecting information about customary law (in his work he cited 70 articles of the adat) from the famous biys of the Middle Zhuz, the author said that no one remembers the name of the "inventor" or the time of their adoption, but a rare biy does not know them. Along with this, S. B. Bronevsky (1830), noticed that with a seeming lack of authority among the Kazakhs, since "there is no person whose command, society, or the family in particular, would be ready to obey", however, clan relations were decisive for the life of the community and made it possible to control the actions of each fellow tribesman. For public administration, a set of laws was developed (most likely, legal norms were meant - "the most necessary laws" of the Tauke Khan era), according to which "majestic biys" dealt with issues of legal proceedings between Kazakhs Bronevsky (1830), who, upon receipt of the complaint, tried to understand in detail and in detail the essence of the claim. The process of consideration of the claim, according to the author, is lengthy, but it allowed all parties to the process to appear during the judicial investigation. S.B. Bronevsky (1830) noted that the biysjudges in their arguments during the sentencing were based on specific examples from judicial practice, therefore, "claims end with a decision executed without murmur and objection". 
The peculiarity of the trial, according to the official, was that the skillful biy in the course of solving the case tried to reconcile the parties, for this he used all his eloquence, knowledge and life experience.

A similar characteristic can be found in the works of other officials. Of interest are the materials collected by the Boundary Commission in 1846, since the information collected in them differed in many respects from those available at that time. On breadth and depth of coverage of questions it is possible to allocate reports of the Lieutenant d'Andre (1998) in which he one of the first noted the existence of the criminal investigation in the Kazakh judicial process. He wrote: "If the Horde comes to Biy with a denunciation of any offense of strangers to him, in this case the Biy proceeds to the proper search and if such a denunciation warned the crime or could benefit, the informer receives nothing but the approval of the Biy". False denunciation entailed admonition and if it did not bring someone a loss, "the informer is punished with rods at the discretion of the Biy and since then has no right in any case to appear to the Biy with any complaints" (d'Andre: 1998, 167). Therefore, denunciation as the reason for the search did not cause condemnation of society and was obviously an element of the search system.

However, the information of d'Andre is not fully confirmed in subsequent materials under customary law. So, a member of the Semipalatinsk Statistical Committee Makovetsky (1998) wrote in 1886: "The Kyrgyz do not see anything wrong with the false denunciation made to the Russian authorities. Other denunciation generations, on the contrary, provoke a heated protest, and the scammers themselves are considered bad people. Many abusive expressions are attached to them: "beldruchi", "jalakar" - a telltale, "utryukchi" - a liar, "yekchi" - a gossip, "bulyukchi" - a rebel, "bzuvchi" - a disorder". Such contradictory data of adat researchers most likely indicate variability in their application and are possibly associated with the social field of the clan and community. So, if a denunciation was made in relation to a homogeneous person, then, undoubtedly, such an act was considered bad in the eyes of his relatives, as he was associated with the concept of “betrayal". In Colonel Pevtsov's notes on the adat of the Younger Zhuz we read: 
"Many of us were witnesses of how the Kirghiz died, by definition of a kind, a shameful execution in satisfying the Russian demand for extradition of criminals, fictitiously accepting crimes in order to only distract the storm from the whole kind" [RSHA. F. 183. I. 1. C. 18. Sh. 13].

At the same time, if the honor of the clan was affected, then the denunciation of the foreigner was considered as an action aimed at protecting the whole clan, so he found approval among the bloodlines.

One of the functions of biys in the preliminary investigation was the collection of evidence in the case. D'Andre (1998) pointed out this circumstance in this way: "The digging in the wagon or the julameika is carried out either by the biy himself, or through a person authorized by him, with two Kirghiz to him with two strangers from from the alien village appointed by the biy", that is, the search for the necessary evidence or evidence was carried out by the biy or his proxies.

At a later time, after administrative reforms of the XIX century the judicial process on the territory of Kazakhstan was changed: the search functions, along with those preserved by the biys, are transferred to the investigating authorities of the county administration, apparently with the aim of controlling and limiting the powers of the people's court. However, in traditional society, these functions were assigned, judging by the reports of d'Andre, not only to the victim, but also to the biy.

D'Andre's information is particularly interesting because it was noted almost all the stories about the judicial practice of the biy that the elements of the search by the biy were not generally characteristic of the Kazakh judicial practice. Judicial and investigative actions are the responsibility of the plaintiff, i.e., filing a claim, search for clues and evidence, bringing witnesses, etc. is a purely personal matter of the victim. To interfere in his actions no one except the community had no right. The biy's search activities are connected, obviously, with such offenses that entailed a threat to the existence of the collective, hindered its integral development, perhaps the severity of the offense was so great that it entailed the disintegration of the community into small subgenera, which was dangerous in the development of extensive nomadic 
economy. The integrity of the entire community as a system came to the fore. Further, d'Andre (1998) noted that after the initiation of the case, the accused, in case of refusal to voluntarily appear at the Court of Biys, was detained by the forces of public order: according to customary law, the biy is authorized to "extract the person from the village through relatives" or through a trusted person who received a special assignment from the biy. In addition, judging by the report of the provincial secretary Beglov, the judges had the yesaul, who "receives from every ten cattle of any kind" for his services [RSHA. F. 400. I. 1. C. 685. Sh. 189]. Obviously, the yesauls are the organ of coercion that brought the decisions of the biy to life.

Official sources attributed its accusatory nature to the peculiarities of judicial practice, which in the conditions of domination of family relations was a means of collective assistance and responsibility. Virtually all archival materials note the clan's collective responsibility: "In the tribal life, the Kirghiz - all clan members are more or less responsible for one, and one for all - and the insult inflicted on one is considered an insult to the whole clan, which makes murders and other serious crimes relatively rare" [RSHA. F. 183. I. 1. C. 18. Sh. 13].

At whatever stage of the investigation, it was the self-help of the clan team that provided the plaintiff with justice, whether it was the discovery of the perpetrator, his capture, appealing to the court of biys, holding to account, in the end, the same barymth that he could not make alone, - in all these cases, all of his actions are directed by the collective, it is he who is the vector whose adherence ensured the victory in court to the victim. Self-help of the victim is a key point in the trial. That is, even if all the formalities of the lawsuit are followed, the enforcement of the sentence of the biy depended largely on the actions of the plaintiff.

In the second half of the XIX century there were publications which also noted that the if ongoing administrative and political reforms really changed the judicial structure in the Steppe, however, the trial itself in the trial courts (court of biys) did not undergo significant changes. As before, in the distant Kazakh villages, ordinary nomads turned to the biy, who considered all lawsuit cases on the basis of legal customs. Litigators gathered for 
the trial of biys - plaintiffs and defendants, as well as everyone who wanted to listen to the judicial debate and find out the latest news from all the outskirts of the vast Kazakh steppe.

However, certain changes occurred in the procedural issues of the Court of Biys. Thus, Valikhanov (Valikhanov, 1984) wrote that if all lawsuits basically used to arise at the request of the plaintiff, then at present there was a practice of initiating cases "according to the message of the administrative authority". Valikhanov's information was confirmed in "The project on the abolition of people's courts in the Turkestan region" prepared by the prosecutor of the Tashkent Trial Chamber Nenarokomov in 1913, which said: "As a general rule, all cases, both criminal and civil, start with sole judges on complaints, and for nomads according to the volost governor or county governor" [Central State Archive Republic of Uzbekistan. F. I-36. I. 1. C. 6009. Sh. 157 turnover]. Grodekov (1889) expressed the same opinion: "Biy, who knew about a crime for which no complaint was filed, could carry out a search about it, along with elders and respected persons". It should be highlighted that in pre-reform times, the biys (like other persons) were not the initiators of the lawsuit - all such procedures fell on the plaintiff and his relatives.

In another source on customary law, Samokvasova, one can find the norm according to which the rights of the yesaul for the delivery of the suspect to the court were expanded. And if the provincial secretary Beglov used to only mentione the yesaul as messengers of the biys, then Samokvasova asserted: "If the messenger of the one for whom he was sent will beat and make wounds, or kill, then there is no punishment and a token, but pays full kun for the murder" (People's court in the Turkestan region, 1870). If the yesaul himself used force against being brought to court, which did not offer resistance, in this case to the authorities, then he was responsible before the court for his illegal actions (People's court in the Turkestan region, 1870).

To resolve the dispute, the plaintiff and the defendant were asked to choose one biy, mainly from their own volost (sometimes the choice fell on the biy from another volost, but it had to belong to the plaintiff's family or the respondent's family). In more important cases, each side chose two or three or 
more biys; in the case of particularly complex cases, their number could reach twelve. In case of disagreement between the biys of the defendant and the plaintiff, who were always chosen equal number, to manage the congress, they were elected jointly or appointed by the representative of the regional administration as a mediator (from other clans), whose voice resolved the case completely by joining it to one or the other side (Ibragimov, 2006).

In order to consider the complaint, biys gave each party the right to express their complaints, then the witnesses of the parties received the right to confirm or refute. As an innovation of this process, we can mention "consideration of the presented documents" (Ibragimov, 2006). Taking into account that Kazakh society was characterized as a whole by an unwritten culture, the appearance of various kinds of references, documents, notes, etc. can be considered an important innovation of the second half of the XIX century. In the Kazakh legal proceedings.

Translator and ethnographer Ibragimov (2006) noted that upon receipt of the claim, the defenders carefully listened first to one side - the plaintiff, then the side of the defendant. At the same time, to clarify the circumstances of the case, both for themselves and for the listening audience, biys often "ask one side or the other, give examples, catch on the word quirky Kyrgyz, and thus, trying to arouse general approval from the public, show their abilities, using such methods to discover the truth, which are usually attributed to the duties of a lawyer, not a judge".

Both parties, as a rule, were satisfied with the decisions of their judges, but in case of dissatisfaction with the decision made or to increase the objectivity of the process, it was always possible to replace the composition of the biys, to invite several biys from other volosts, bringing their number to twelve.

The fact that the court met the needs of the Kazakh society according to ancient customs was noted by the Russian general and oriental scholar Kostenko (1880): “The people, in any case, are satisfied with it and prefer the court according to their ancient customs to our criminal or civil judicial practice, which is resolutely inaccessible to its concepts". Often, Kazakhs deliberately hid from the Russian authorities some types of crimes (especially those related to criminal) in the hope that it would be possible to file a lawsuit with the biy, 
who would judge the case under customary law.

As Makovetsky (1998) wrote, the biy could not make a mistake during the investigation. The open steppe, the public environment served as an insurmountable obstacle to concealing the traces of the crime, so that the slightest violation of law and order became the publicity. "With the Kyrgyz public, with constant visits and trips from the aul to the aul, in the steppe every find is very quickly discovered, every new thing that has appeared in one or the other. The news of the victim diverges equally quickly, and therefore it is very difficult to hide the find and almost always the lost thing is returned to the hands of its owner, which is expressed by the Kirghiz in the following proverb: “Тапқан сүйіншіні, таныған алады" - "The finder rejoices, the identifier will take it".

The open nature of the nomadic society served as an obstacle not only to conceal the crime, but also to the likelihood of perjury. In matters of special importance, the biy provided an opportunity for no less than three witnesses, relatives of each side, to vouch for the veracity of the words of the bloodsucker. But if the witness's testimony was knowingly false, since his goal was to whitewash his relative in the eyes of the community, then such an offense sooner or later became known to everyone. "It is difficult to hide anything from the attention of its inhabitants in the steppe, and therefore the Kyrgyz, who falsely entrusted the innocence of the accused relative, will sooner or later be caught, as well as the false witness, according to popular custom, is deprived of the protection of society, moreover, the author added, - his property can be plundered and he himself is killed with impunity ... No one will dare to perjury" (Ibragimov, 2006).

When resolving legal disputes, biys applied various experiments and studies requiring special knowledge. Much later, this practice was transformed in procedural legislation into special techniques from the field of forensic science, forensics, etc. For example, in the legend brought by a connoisseur of history and ethnography of Kazakhs Kraft it was told about the procedural actions of the judge.

Many people constantly flocked to resolve pressing everyday disputes to one biy, who was famous for his wisdom and justice. Once, two men turned to him, one of whom was a mullah, and a 
woman. The argument was about a woman: both men proved that she was his wife. Then the butcher and the buyer came to the biy, who during the sale failed to divide the chervonets. The last to address the biy that day were two men, one of whom was the biy. A dispute arose over the horse: each of them assured that it belonged to him. To all the litigants, the wise biy appointed the next day to resolve arisen disagreements.

And then the biy announced all his decision to them. The woman was the wife of the mullah, since she cleaned the inkwell offered by the biy very carefully and accurately, and therefore the biy concluded that she knew how to handle stationery; the other applicant was illiterate. The judge gave the chervonets to the butcher, since when the coin was lowered into hot water, greasy spots surfaced on the surface of the water. The dispute of the third group caused particular difficulty. But the biy successfully resolved it as well. Having suggested participants of dispute to pass several times by the horse standing in a number of other horses, he saw that when the participant in the litigation approached it, the horse "recognized its owner and looked kindly" (Kraft: 1900,
82). From which he concluded that the horse belongs to that biy.

The legend cited indicates that when resolving disputes special knowledge was used and procedural actions were carried out the biy: a woman's marriage was determined by using a judicial experiment (cleaning of writing instruments); the ownership of the chervonets was determined by using a forensic examination, which revealed the presence of greasy layers on its surface; the owner of the horse was determined as a result of such judicial action as identification, and initially each of the disputes had to identify the horse, but the decision was made according to the behavior of the animal.

Thus, the legend confirms: when resolving court disputes, biys applied both general knowledge of adat norms and special information, as well as special techniques.

A well-known local historian, researcher of the Orenburg region Dobrosmyslov (1904) reported about himself that he had served "18 years in the Kyrgyz steppes as a veterinarian, peasant chief and chairman of the county congress of peasant chiefs ... he devoted his free time to studying the region in archaeological, historical, economic and 
ethnographic relations, as a result of which up to 150 typewritten works about the Kyrgyz were published in various scientific journals in the form of separate books and brochures". $\mathrm{He}$ also investigated the judicial system in the Turgai region. Studying justice directly in the steppe, the author left interesting information about the court of biys, which at the beginning of the twentieth century was only the remnants of the former judicial system of the Kazakh people.

In order to consider the evolution of judicial practice in the Kazakh region, Dobrosmyslov (1904) shows the action of the court of biys, starting from the Khan era. He reported that at that time the Kazakhs had the right to turn to the case, not only to the ruler or elder of the village to which they belong, but also to the khan himself. The peculiarity of the judicial system under Kazakh unwritten law, the local historian noted, was that the lawsuit could be filed only by the injured party, and only in this case the biys had the right to consider it in court. Not every incident that happened in the eyes of a nomad is a crime, a public evil, but only one that has been complained by the victim: "A court case can only begin with the victim and cannot be punished if there is no victim or he reconciled with the criminal”.

To resolve the conflict, the parties chose the biy at their request and, as a sign of complete confidence in the decision of the judge, threw kamshy (lashes) before him. "As a rule, the plaintiff and defendant, if they themselves came to an agreement on the need for a court or were forced to by relatives, elected a person as a judge, appeared before him and threw shreds before him ... and this was recognized as an obligation to obey the decision" (Dobrosmyslov, 1904). Throwing a whip before the court meant the parties unconditionally agree with the decision of the judge, a kind of act of recognition of any punishment that may follow the sentence. Although, if the formal procedures of the trial were not followed, such as: publicity, transparency, openness, or a judge, in the opinion of one of the parties, was biased, all this together gave rise to those who were trying to turn to another judge to review the case.

Tribal relations dictated social rules, the observance of which was considered mandatory for every nomad. Ensuring the appearance of the defendant and the plaintiff to the court of 
biys was the business of the whole community, since it was in court that the protection of the honor and dignity of separation, subgenus, clan, as a whole, of the whole tribe took place. For collecting evidence, the biys brought to trial witnesses, who should be "at least two and sometimes three". If neither the defendant nor the plaintiff could provide such for their defense, then the biys resorted to the oath, which neither the plaintiff nor the defendant could take: "People known for their honesty should swear for them" (Dobrosmyslov, 1904).

We find the same information about the court of biys at the Russian publicist, orientalist and lawyer Gurland (Gurland, 1904). Works by Gurland and Dobrosmyslov were written almost simultaneously, therefore the data presented in them are interconnected and complement each other. One of the few customary law researchers, Gurland studied the evolution of steppe legislation from ancient times until the end of the 17th century, compared the customary law of the Mongols with the law of other nomadic peoples, and found many similarities that unite the nomads of Eurasia. Noting the role of biys in resolving conflicts in the steppe, the scholar paid great attention to such institutions of traditional society as mutual responsibility, patrimonial responsibility and patrimonial dependence (genti adscriptio) (Gurland, 1904). The mechanism of patrimonial institutions extended not only to the ordinary member of the community, but also to his family, clan as a whole, and the biys played a significant role in regulating this mechanism. Dependent on their decision was "solidarity and the absence of contention and falling away of members of the union" (Gurland, 1904), which were the main conditions for existence. A comparison of the steppe legislation of different nomadic peoples led the author to the conclusion that the legal organization of the Kazakhs is characterized by a low level of development, characteristic of societies of ancient times.

Not always litigating parties could clearly and intelligently explain their arguments or excuses. In such cases, they resorted to the help of intermediaries, most likely their relatives, who were charged with the obligation on behalf of the appealing the bloodman to present the essence of the matter to the court. The trial was carried out soon, without red tape, without any preliminary research and questioning. 
The basic principles of the court were based on the personal judicial experience and authority of the judge, whom both parties fully trusted. This is a characteristic given by Slovokhotov (1905) to everyday litigation of the Kazakhs. Cases of special importance, among them: "Disputes in which different births were interested, blasphemy, the murder of the Sultan", dealt with a large gathering of people with the participation of the Khan himself in the days of commemoration or crowded folk festivals.

In the research's opinion, such rather "simple" justice was not impeccable; it had its drawbacks, especially noticeable to a person accustomed to written codified laws, where the norms are clearly indicated and their interpretation depending on objective and subjective circumstances, the parties' desire and the judge's level missing. But the researcher was struck by the unlimited faith of the Kazakhs in their biys, as "proven by practice, the ability to understand troublesome issues, which makes it possible to confirm his sentence with the prestige of kindred power; old age, which naturally inspires honor and respect, especially where one cannot yet give due respect to the qualities of the mind and heart - these are the bases on which the deep faith in the infallible sanctity of the verdict of the people's judge - biy was held. For all that, the defendant could eliminate for some reason an undesirable judge for him" (Slovokhotov, 1905).

Slovokhotov (1905)., like other researchers, noted the collective actions of the community to protect the honor not only of an individual, but of a kind: "If the guilty person (defendant) fails to appear for the court's judgment or is not able to pay, the remuneration is paid to the victim's relatives or same-village men of the above-mentioned defendant".

\section{Conclusion}

Thus, with the beginning of close Russian-Kazakh contacts, the Russian authorities made efforts to obtain as reliable information as possible on the nature of local law. Along with studying the institute of biys, research optics was aimed at analyzing the judicial process of adat.

An analysis of the sources suggests that, despite the generic diversity, the adat rules governing the court and the process, as a whole, had a single content. This conclusion can be reached, since the sources of legal norms 
are generalized and have a common characteristic.

Pre-revolutionary researchers correctly noticed a number of features of the Kazakh court: openness, publicity, speed, trasparency, etc., which generally ensured the stability of the nomadic life of the Cossacks.

At the same time, the researchers of the Kazakh society, transferring the traditions of Russian life to the Kazakhs, exaggerated the immaturity of the social structure of the nomads, hence the attitude to the adat, which was based on the principle of collectivity, as a primitive, tribal law.

\section{References:}

Bronevsky, S.B. (1830). Notes on the Kyrgyz Kaisaks of the Middle Horde. Domestic Notes, (41-43), 194-285.

D'andre, (1998). Description of Kyrgyz customs having the force of law in the horde, In T.M. Kulteleev, M.G. Masevich, G. B. Shakaev (Comp.) Materials on Kazakh customary law. Almaty: Zhalyn.

Dobrosmyslov, A.I. (1904) The court of the Kyrgyz Turgai region in the XVIII and XIX centuries. Kazan: Typographic lithography of the Imperial Kazan University.
Grodekov, N.I. (1889). Kirghiz and Karakirgiz of the Syr-Darya region. Legal life. Tashkent.

Gurland, Y.I. (1904). Steppe legislation from ancient times to the 17th century. Kazan: Typographic lithography of the Imperial University.

Ibragimov, I.I. (2006). Notes on the Kyrgyz court. Almaty: Zhety zhargy.

Kostenko, L.F. (1880). Turkestan Territory. The experience of militarystatistical surveys of the Turkestan military district. Materials for geography and statistics of Russia, 1, 350.

Kraft, I.I. (1900) From Kyrgyz antiquity: (Sultans, Tarkhans and Bii). Orenburg: F.B. Sachkov Publisher.

Makovetsky, P.E. (1998). Materials for the study of legal customs] In T.M. Kulteleev, M.G. Masevich, G. B. Shakaev (Comp.) Materials on Kazakh customary law. Almaty: Zhalyn.

Mazhitova, ZH.S. (2014). Place and Role of the Biy Council and People's Assembly in the Traditional Kazakh Society of the XVIII - XIX Centuries (Following the Data of the PreRevolutionary Russian Historiography). Asian Social Science, 20(10), 129-136. Mazhitova, Zh.S., Abzhapparova, B.Zh., Aytbay, R.T., Kushpaeva, A.B. (2016). The Institute of Biys in the Imperial 
Russia and Early Soviet Period: From

Reforms to Abolishment. Indian Journal of Science and Technology, 22(9), 1-7.

Nazarov, F. (1821). Kyrgyz. Bulletin of Europe, 119(16), 314-321.

People's court in the Turkestan region. (1870). Government Gazette, 277, 2-3.

Samokvasov, D.Y. (1876). A collection of customary law of Siberian foreigners. Warsaw: Printing house of Ivan Noskovsky.

Slovokhotov, L.A. (1905). People's Court of Customary Law of the Kirghiz of the Lesser Horde. Orenburg: Turg. reg. tipo-lit.

Valikhanov, C.C. (1984). Collected Works V. 4. Alma-Ata: Science 